\title{
特集「グローバル社会と不動産」にあたって Real Estate Issues for Global Society
}

室田 昌子（東京都市大学 出版編集委員）

Masako MUROTA

社会のグローバル化が進展するなか, 不動産についても取引・投資, 活用などで外国人との関 係性が強まっており，また生活や地域社会などでも外国人との関わりが拡大している。訪日外国 人が増加すれば, 当然, その滞在期間などに応じた多様な滞在場所が必要となるが, 滞在場所の 確保や問題解決のための制度が不十分であり，増加する訪日外国人の実態に十分に対応できてい ない。

その結果, 多くの外国人が適切な滞在場所や生活場所を見つけることに苦労し, 自らの居住用 不動産の取引をめぐって不満を抱えている。それらのニーズに対応すべく，民泊やゲストハウス， シェアハウスなどの新たなビジネスが民間ベースで急速に進展している。しかしながら制度対応 が不十分な部分があり，昨今のネットワーク社会での個別取引の実態把握と対応の難しさもあり， 制度的なグレーゾーンが拡大化し，一方で，これを悪用する事業者の増加が指摘されている。そ の結果, 人々の居住する空間等で生活マナーの問題や地域社会でのトラブル, さらに不特定利用 者の増加による安心感やコミュニティ衰退などが問題視されるという, 悪循環にさしかかりつつ ある。このなかで短期滞在を中心とした民泊のあり方については検討が進んでおり，1つの解決 方向が見いだされようとしている。

これらの不動産の問題は, グローバル社会のありように関連づけて解決されるべきであろうが, グローバル社会のありように対する社会的コンセンサスは得られておらず，しかもグローバル化 が進展するほどにさらに多様な議論が噴出すると考えられる。そしてこの問題は, 各国でその方 向性や解決策が異なっていることからもわかるように国民性や地域性に深く根ざし, しかも, 政 治・制度的側面, 経済的側面, 社会的側面, 地域・都市づくりなどの諸問題に関わるために解決 策は多方面にわたり複雑である。また, 一旦, 制度を決定すると, その後に制度を変更しても変 更以前の状態が実態的には継続しやすく，その点で不可逆的な特徴を有する。このような状況か ら，推進・慎重・反対等の立場があり，その理由も多岐にわたることになる。

私たちの社会は，根本的な方向性や解決策が容易には見いだしにくいなかで，実態的に進展す るグローバル化に対応することが迫られている。なかでも不動産の問題は, 外国人の生活や滞在 の場に直結するために端的に問題が表出しやすく, グローバル化の最前線に立たされている業界 と言えるだろう。一方で，空き家問題などの住宅ストック活用への突破口としても期待されてい るところであり, さらに観光産業の発展や地域活性化への効果も期待されている。そのような観 点も含めて, 日本的な解決策を導き出すためのとっかかりとなることが求められる。

本特集は，このような背景を踏まえて，日本に滞在する外国人の滞在・居住施設に関わる法制 度的な問題, 不動産取引や利用・投資とその課題, 多文化共生社会をめざした制度や取り組みと その課題を紹介する。不動産事業としては短期滞在のみならず中長期滞在は重要であり, 従って 民泊に加えて，一般の居住問題も取り扱っている。 
短期・中期・長期の滞在期間に応じて, 施設も必要な支援も異なる部分があるものの共通事項 もあることから, 総合的に考えるための題材を提供している。主な観点としては, 制度的な検討 や法律上の課題, 不動産事業の実態や課題, 社会的な多様な取り組みと課題をとりあげている。

まず，法制度的な検討として，国における民泊の検討に焦点をあてた論文が西海氏の「外国人 の日本での不動産活用の実態と課題〜民泊を中心に」であり, さらに民泊に関する法的論点を取 り上げ仕組みの方向性を示した論文が福井氏の「民泊の法的論点と政策」である。また，国家戦 略特区の民泊を全国に先駆けて導入した大田区の制度と取り組み実態・課題が，「国家戦略特区 制度を活用した大田区の『特区民泊』事業について」で紹介されている。

不動産事業としての動向や実態として，まず不動産賃貸業が直面する問題とそれに関わるきめ 細やかな支援や活動を荻野氏の「グローバル化で求められる不動産業とは」が示しており，さら に外国人による不動産投資に関する問題や今後の見通しや推進策を佐藤氏の「外国人の日本での 不動産投資」が示している。

また, 多文化共生社会にむけての取り組みとして, 外国人の多様化とそれに伴う課題の多様化, 特に集住地域と分散地域に焦点をあてて山本氏が「外国人住民の居住をめぐる問題の諸相一一集 住地域・分散居住それぞれの課題」を論じ，また外国人留学生に特化して居住施設の実態や確保 の問題について田中氏が「留学生の居住施設確保方策と課題」が論じる。そして, 稲葉氏が外国 人住民に関わる問題や居住支援の取り組み, 特に多様化する外国人への多様な支援や課題を「多 文化共生社会における居住支援の取り組み」で論じている。

本特集は, 以上のような多面的な角度からグローバル化に対して不動産業とそれを取り巻く社 会が直面している実態と課題, 今後の方向性を示しており, 大変興味深い内容となっている。ス トック活用, インバウンド対応, 外国人投資, グローバル対応の法制度の遅れ, 旅館業と不動産 業の違い, 民泊制度, 地域経済活性化への結びつけ, 多様化する外国人や留学生, 集住と分散等 の居住形態と外国人, 多様なトラブルと多様な支援の取り組み, 多文化共生社会の実現への課題 などの多くの観点が浮かび上がった。

日本におけるグローバル化の議論はまだ緒に就いたばかりではあるが，今後，急速に進展する グローバル社会において，共生しうる社会を目指す上で不動産業や居住政策・まちづくりがさら なる役割を果たすことにつながれば喜ばしい限りである。 